\title{
Predictors of Collateral Learning Transfer in Continuing Vocational Training
}

\author{
Anja-Christina Hinrichs \\ University of Bremen \\ Institute Technology and Education (ITB) \\ Am Fallturm 1, 28359 Bremen, Germany \\ E-mail: anja.hinrichs@uni-bremen.de
}

Received: 15 July 2014; Accepted: 12 August 2014; Published online: 31 August 2014

\begin{abstract}
Against the background of demographic change and skill shortages continuing vocational training is of great significance in Germany. However, the training effectiveness is mostly assessed only at the end of a training program or several months after the training. Since in continuing vocational training the two contexts learning field (training) and performance field (work context) act simultaneously, the presented study investigated whether there are already situations in the work context which allow the application of newly acquired knowledge in parallel with the training. The main focus lies in the identification of predictors of learning transfer that takes place alongside the training participation and in the investigation of their causal relationships. Using structural equation modelling five latent variables were identified which have a significant effect on learning transfer parallel to the training - the so called collateral learning transfer. These five predictors explain together $62 \%$ of the variance of collateral learning transfer (gathered as performance improvement at work).
\end{abstract}

Keywords: collateral learning transfer, learning transfer, job performance, vocational training, CVET, structural equation modeling

\section{Bibliographical notes:}

Anja-Christina Hinrichs, M.Ed., M.A. is a researcher at the Institute Technology and Education (Institut Technik und Bildung, ITB) at the University of Bremen, Germany. Her research interests focus on learning transfer, work-based learning, and job performance. 


\section{Introduction}

The legitimation of vocational training is of central importance regarding the investments made. Therefore, it is not surprising that the design of training measures is currently leading the list of challenges within vocational training (SCIL trend study, Diesner and Seufert, 2010). The two questions "What effects are noticed in the work context?" (outcome-oriented research; Kirkpatrick and Kirkpatrick, 2006, Philipps and Schirmer, 2008) and "Which parameters contribute to knowledge development and knowledge transfer?" (process-oriented research; Holton et al., 2000; Bates et al., 2007) are discussed in separate lines of research. Practice and research in continuing vocational training (CVT) are currently dominated by these two approaches. However, a linked study of process and outcome data would be a necessary condition in order to evaluate and improve the effect of training in the work context (Desky and Tessaring, 2006). Baldwin and Ford defined learning transfer as follows: "For transfer to have occurred, learned behavior must be generalized to the job context and maintained over a period of time on the job." (Baldwin and Ford, 1988, p. 63).

In this respect, Gessler (2012) argues that the movement from learning to application does not imply that knowledge from the learning field may easily be transferred to the work environment or performance field. A more sufficient term or concept would be "transformation" because learning transfer in vocational training is more like a context-based transformation of knowledge. If both contexts - learning and performance field - have an effect at the same time, transfer takes place parallel, not sequentially. On one hand, transfer occurs as transformation within the learning and the performance field, and on the other hand, these transformations build resources for the respective other field. In this understanding, the learning field rather exists "beside" the performance field, not after it, and the effects are mutually reciprocal, not unilateral.

To evaluate the impact of training, most commonly trainee reactions are collected. These are based on the assumption that the satisfaction allows conclusions on the learning success. But is successful learning transfer so easily to describe or is it rather the interplay of complex causal relations of predictors?

Previous research results show no significant relationship between satisfaction scores and the learning and transfer success of participants and the implementation and application of learning in the work context. Satisfaction surveys alone tell us little about the actual capacity of the transfer of the newly acquired knowledge in behavioral changes. Statements about the actual learning and transfer success thus should not be taken on trainee reaction scores only (Alliger et al., 1997; Ruona et al., 2002; Wirth et al., 2009; Gessler and Sebe-Opfermann, 2011).

But what predictors have an impact on successful transfer of the learned to the workplace and when does the transfer of learning happen? The presented study is aiming at answering these questions.

In contrast to the traditional understanding of learning transfer, where successful transfer of learning takes place when the learning is generalized and sustainably used in the workplace over a period of time (Baldwin and Ford, 1988), the present research study underlies the assumption that learning transfer already occurs parallel to training, and not necessarily only after the completion of the training. This assumption is based on the theoretical framework model of Gessler (2012), which emphasizes the presence of the transfer situation in the work environment of the learner as a prerequisite for learning transfer in addition to the 
sustainable use of what is learned. In this respect, knowledge is neither linearly transferred from a learning field (e.g. a training) to a performance field (the work context), nor are these two contexts to be considered completely separate. The context learning field is, in contrast to the overarching performance field, limited in time - a special feature of continuing vocational training (ibid.).

Since in CVT the learning field and the performance field act simultaneously, it is to investigate whether the work performance of the learner is already improving through application of the training content before the end of the training. Accordingly, the main focus of the study presented lies parallel to the training participation both on the identification of predictors of the learning transfer, and on the investigation of causal relations between the predictors of learning transfer.

For this purpose, it makes sense to link process and outcome data (Descy and Tessaring, 2006). In such coupled investigations both the learning and transfer processes (process-oriented research; Holton et al., 2000; Bates et al., 2007) and the impact of training in the work context (outcome-oriented research; Kirkpatrick, 2006, Philipps and Schirmer, 2008) are considered. In the past, both research approaches have been considered mainly as two separate lines of research (Gessler, 2012).

In the present research study process and outcome data are collected both in the learning field and in the performance field to investigate learning transfer (as improvement in work performance) during CVT.

The investigation thus takes place on the meso-level of the transfer term as newly learned is transferred from the learning field (source) to the performance field (real application context, target) (Hense and Mandl, 2011; Mandl et al., 1992).

\subsection{Study purpose and significance}

Contrary to the widespread understanding of learning transfer (generalization and maintenance of the learned after the training, see Baldwin and Ford, 1988), it is assumed in the present research, that an increase in performance in the workplace through the application of learning content already takes place parallel to CVT.

Since this phenomenon has not been described in the literature yet, it makes sense at this point to extend the classical understanding of learning transfer and to introduce a new term:

\section{Collateral learning transfer}

Collateral learning transfer refers to learning transfer which occurs as an improvement of performance in the workplace already parallel to the training. The term "collateral" (Latin collateralis) means parallel, together with, accompanying, alongside.

In education, the term "collateral" is not new. Collateral learning is a learning process, which takes up the previous experience of the learner and leads to further acquisition of knowledge. Unlike incidental learning, collateral learning comprises the imparting of knowledge (Faulstich, 2009; after Dewey, 1938).

From a business perspective Lee, Johnson and Grewal (2008) speak from collateral learning in the context of the establishment of strategic corporate alliances for the development of new products. In this regard, collateral learning results from the activities and experiences of the collaboration and acquisition of new product development knowledge in the alliance. The individual and collective factors in the alliance or the similarity of the organizations determine the extent of collateral learning. Within the alliance collateral learning takes place parallel in the 
individual companies where deeper and new product-related knowledge arises (Inkpen, 1998; Miner et al., 2001; Lee et al., 2008).

Within these alliances, in which each company is a separate context, collateral learning arises accompanied by activities and experiences in the interplay of these contexts (Moorman and Miner, 1998). This simultaneous functioning of (at least) two contexts is also given in the case of the research approach of the present study through the learning field and the performance field. Here, learning transfer occurs parallel, thus collateral, to further training.

For the purposes of this study, therefore, transfer of learning which happens already accompanying the continuing vocational training is referred to as collateral learning transfer. The main focus of research presented in this paper is the identification of the predictors of collateral learning transfer and its causal relations.

\subsection{Research questions}

In order to find support for the assumed new transfer term collateral learning transfer, it is investigated first, whether learning transfer (as improvement of performance in the workplace) already occurs parallel to the training.

Research question 1 :

Does learning transfer already occur parallel to the training?

Moreover, it is of interest, what predictors actually have an effect on learning transfer parallel to the training.

Research question 2:

What are the predictors of collateral learning transfer?

Finally, and to get a greater understanding of the phenomena collateral learning transfer the causal relations between the predictors are analyzed.

Research question 3:

In which causal relations do the predictors have an effect on collateral learning transfer?

In the next section, the methodology of the study will be explained. 


\section{Methodology}

Whereas the identification of factors of learning transfer has been intensively researched internationally, the structure of linkages has been mostly neglected. That is why Cheng and Ho (2001) - as part of their meta-analysis of studies of the years 1989 until 1998 - recommend on one hand the validation of the factor structure and on the other hand the usage of structural equation modeling for further research studies in this field. This recommendation has not been seized on with only a few exceptions, such as Yamkovenko (2009) who analyzed a factor model of personality, self-efficacy, goal orientation, and intent to transfer training on the job, and Gessler (2012) who also examined the structure of the factors of learning transfer by integrating process and outcome data (as mentioned above).

Causal dependencies between latent variables can be tested with the help of structural equation modeling. Therefore, content related hypotheses are linked in the model and tested by the empirically obtained data. The correlations between the variables are tested and the variance of the dependent variable will be explained (Reinecke, 2005).

Following the assumption mentioned above that learning transfer takes place parallel to CVT data of the professional and the social-communicative performance of learners is collected during the training participation. The online-questionnaire is based on the pre-study of Gessler (2012), but further developed, adapted to the different research design and complemented by additional latent variables such as self-efficacy and work identification. Therefore, existing inventories (i.a. Holton, Bates and Rouna, 2000) and meta-analysis have been considered (i.a. Blume et al., 2010; Mandl et al., 1992).

\subsection{Sample and data collection}

Project management has been selected as domain for the study. With approximately $37 \%$ share of the company work processes (with increasing tendency) project work and the related project management represent a key operational field (Rump et al., 2010). The study is carried out in a field which implements innovations in enterprises and thus is highly relevant (Gessler, 2010). At the same time, this selection is also a limitation which is weakened by the consideration of different company contexts and sectors in the context of intercompany training.

The study participants are taking part in a standardized project management program, which is carried out Germany-wide and ends with a certification that is recognized by companies. The course includes a "kick-off" day, 10 attendance days (spread over 3-4 blocks) and the certification. The total duration of training extends over a period of about 4 months. On the basis of a unified concept of the training course the training is performed by different trainers who have all gone through an extensive training and certification process for authorization. The content, materials and methods of the course are also standardized. This uniform setting is of importance because trainings without such quality assurance processes might probably have a different weighting of the predictors of collateral learning transfer.

The data was collected after training day six. The sample consists of 299 participants (72.2\% male, $27.8 \%$ female) coming from 82 Germany-wide project management training courses. The age of the respondents was between 20 and 57 years. $50.5 \%$ of participants were between 25 and 34 years old. Within this age group, 30 to 34 -year-olds had the largest share (30.5\% of all 299 participants). A 
majority of the respondents reported to have a college degree (239 of 276 participants). With a percentage of nearly 30 percent each, the participants come from the two most represented sectors software industry as well as consulting, training and coaching.

\subsection{Instruments}

Based on outcome-oriented and process-oriented research approaches (see above), especially the Model of the Transfer Process of Baldwin and Ford (1988), the Learning Transfer System Inventory (Holton et al., 2000), and the pre-study of Gessler (2012) have been considered in the present investigation. The following dimensions and latent variables have been studied:

- Trainee characteristics

o Conscientiousness

o Self-efficacy

o Work identifikation

- Training and learning conditions

o Methods

o Situatedness of the learning environment

o Competence support

- Transfer orientation of the training

- Transfer motivation

- Organizational transfer climate

o Transfer climate in the team

o Superior support (attitude)

o Superior support (action)

- Transfer situation

- Transfer success

o Professional performance

o Social-communicative performance

In table 1 each latent variables of the study's instrument is described and an example for an item of each scale is given. 
Table 1: Description of the instrument

\begin{tabular}{|c|c|c|}
\hline Latent variables & Description & Item example \\
\hline Conscientiousness & $\begin{array}{l}\text { Extent to which a person is } \\
\text { reliable, disciplined, and } \\
\text { ambitious. }\end{array}$ & $\begin{array}{l}\text { If I go into a commitment, } \\
\text { you can rely on me. }\end{array}$ \\
\hline Self-efficacy & $\begin{array}{l}\text { Extent to which one believes } \\
\text { in the own skills and abilities. }\end{array}$ & $\begin{array}{l}\text { For every problem I can } \\
\text { find a solution. }\end{array}$ \\
\hline $\begin{array}{l}\text { Work } \\
\text { identifikation }\end{array}$ & $\begin{array}{l}\text { Extent to which one identifies } \\
\text { with his/her work. }\end{array}$ & My work is satisfying. \\
\hline Methods & $\begin{array}{l}\text { Extend to which the methods } \\
\text { of the training support the } \\
\text { learning. }\end{array}$ & $\begin{array}{l}\text { The methods used in the } \\
\text { training support the } \\
\text { learning. }\end{array}$ \\
\hline $\begin{array}{l}\text { Situatedness of } \\
\text { the learning } \\
\text { environment }\end{array}$ & $\begin{array}{l}\text { Extent to which situational } \\
\text { possibilities of application are } \\
\text { shown and discussed in the } \\
\text { training. }\end{array}$ & $\begin{array}{l}\text { Possibilities of application } \\
\text { are presented and } \\
\text { discussed. }\end{array}$ \\
\hline $\begin{array}{l}\text { Competence } \\
\text { support }\end{array}$ & $\begin{array}{l}\text { Extent to which the } \\
\text { accomplishments of the } \\
\text { learners are valued and } \\
\text { supported by the trainers. }\end{array}$ & $\begin{array}{l}\text { My learning attainments } \\
\text { are recognised in the } \\
\text { training. }\end{array}$ \\
\hline $\begin{array}{l}\text { Transfer } \\
\text { orientation of the } \\
\text { training }\end{array}$ & $\begin{array}{l}\text { Extent to which the training } \\
\text { resembles the real work } \\
\text { situation. }\end{array}$ & $\begin{array}{l}\text { In the course I get a lot of } \\
\text { ideas for my practical } \\
\text { work. }\end{array}$ \\
\hline $\begin{array}{l}\text { Transfer } \\
\text { motivation of the } \\
\text { learner }\end{array}$ & $\begin{array}{l}\text { Extent to which the learner is } \\
\text { motivated to apply the learned } \\
\text { at the workplace. }\end{array}$ & $\begin{array}{l}\text { I am motivated to apply } \\
\text { the course content in my } \\
\text { work. }\end{array}$ \\
\hline $\begin{array}{l}\text { Transfer climate } \\
\text { in the team }\end{array}$ & $\begin{array}{l}\text { Extent to which team members } \\
\text { support the application of the } \\
\text { newly learned. }\end{array}$ & $\begin{array}{l}\text { My team members are } \\
\text { open to change. }\end{array}$ \\
\hline $\begin{array}{l}\text { Superior support } \\
\text { (attitude) }\end{array}$ & $\begin{array}{l}\text { Extent to which the superior is } \\
\text { interested in the application of } \\
\text { the newly learned. }\end{array}$ & $\begin{array}{l}\text { My superior appreciates it } \\
\text { when I apply the new } \\
\text { knowledge from the } \\
\text { training at work. }\end{array}$ \\
\hline $\begin{array}{l}\text { Superior support } \\
\text { (action) }\end{array}$ & $\begin{array}{l}\text { Extent to which the superior } \\
\text { discusses concrete possibilities } \\
\text { of application. }\end{array}$ & $\begin{array}{l}\text { My superior discusses } \\
\text { with me how I can apply } \\
\text { the training content at } \\
\text { work. }\end{array}$ \\
\hline Transfer situation & $\begin{array}{l}\text { Extent to which the newly } \\
\text { learned is applied to the } \\
\text { workplace. }\end{array}$ & $\begin{array}{l}\text { Whenever possible, I try } \\
\text { to integrate course content } \\
\text { into everyday work. }\end{array}$ \\
\hline $\begin{array}{l}\text { Professional } \\
\text { performance }\end{array}$ & $\begin{array}{l}\text { Extent to which the learner } \\
\text { increases his/her professional } \\
\text { performance in the workplace. }\end{array}$ & $\begin{array}{l}\text { Because of the PM } \\
\text { training I plan and } \\
\text { monitor the dates in my } \\
\text { projects more precisely. }\end{array}$ \\
\hline $\begin{array}{l}\text { Social- } \\
\text { communicative } \\
\text { performance }\end{array}$ & $\begin{array}{l}\text { Extent to which the learner } \\
\text { increases his/her social- } \\
\text { communicative performance in } \\
\text { the workplace. }\end{array}$ & $\begin{array}{l}\text { Because of the PM } \\
\text { training I have fewer } \\
\text { conflicts within the } \\
\text { project team. }\end{array}$ \\
\hline
\end{tabular}


Using exploratory factor analysis, the scales were tested for single structure, commonality and content validity as well as reduced about items that did not meet these criteria. Only the scales conscientiousness and self-efficacy could not be unambiguously validated due to low communality. The subsequent examination of the internal consistency of the scales (see table 2) resulted in good to average reliability for all scales with the exception of the scale conscientiousness $(\alpha=.672)$, which has only a low reliability.

Table 2: Internal consistency of the instrument

\begin{tabular}{|c|c|c|c|}
\hline Dimensions & Latent variables & $\begin{array}{c}\text { Numbers of } \\
\text { items }\end{array}$ & $\begin{array}{c}\text { Cronbach } \\
\text { Alpha }\end{array}$ \\
\hline \multirow{3}{*}{$\begin{array}{l}\text { Trainee } \\
\text { characteristics }\end{array}$} & Conscientiousness & 5 & .672 \\
\hline & Self-efficacy & 5 & .804 \\
\hline & Work identifikation & 4 & .892 \\
\hline \multirow{3}{*}{$\begin{array}{l}\text { Training and learning } \\
\text { conditions }\end{array}$} & Methods & 5 & .876 \\
\hline & $\begin{array}{l}\text { Situatedness of the } \\
\text { learning environment }\end{array}$ & 3 & .831 \\
\hline & Competence support & 4 & .836 \\
\hline $\begin{array}{l}\text { Transfer orientation } \\
\text { of the training }\end{array}$ & $\begin{array}{l}\text { Transfer orientation of the } \\
\text { training }\end{array}$ & 4 & .885 \\
\hline $\begin{array}{l}\text { Transfer motivation } \\
\text { of the learner }\end{array}$ & $\begin{array}{l}\text { Transfer motivation of the } \\
\text { learner }\end{array}$ & 4 & .912 \\
\hline \multirow{3}{*}{$\begin{array}{l}\text { Organizational } \\
\text { transfer climate }\end{array}$} & $\begin{array}{l}\text { Transfer climate in the } \\
\text { team }\end{array}$ & 4 & .923 \\
\hline & Superior support (attitude) & 2 & .945 \\
\hline & Superior support (action) & 4 & .935 \\
\hline Transfer situation & Transfer situation & 4 & .880 \\
\hline \multirow[b]{2}{*}{ Transfer success } & Professional performance & 6 & .924 \\
\hline & $\begin{array}{l}\text { Social-communicative } \\
\text { performance }\end{array}$ & 9 & .961 \\
\hline
\end{tabular}

In the following section the procedure of data analysis is described.

\subsection{Data analysis}

The overall structure of the quantitative data was analyzed using structural equation modeling (SEM). The strength of SEM lies in being able to model complex causal relations between latent variables (structural model). The second strength of this method is that the latent variables are measured by manifest variables (measurement model), controlling for measurement errors. In contrast, using scale means, which is the predominant approach, is accompanied by considerable bias and represents the gathered trait only in a very limited way (Urban and Mayerl, 2014).

Modeling and analysis of the data is performed with the software Mplus. Mplus uses by default the FIML method (full-information maximum likelihood). In the case of the present study, however, a method has to be chosen which can also compensate for the complete failure of individual participants as the presented results come from data of a longitudinal study. Therefore, multiple imputation had been used. 
In multiple imputation (Rubin, 1987) multiple parameters are simulated and replaced for each missing value. It should be noted that the generated values are only estimates of the true value and do not represent the observed value. Multiple imputation is more effective compared to other methods for dealing with missing values, since a pairwise or listwise deletion of missing data can be avoided and thus no respondents are removed from the analysis. The sample is fully maintained and an analysis by standard methods is possible. In the analysis, differences between the various imputed data sets are taken into account in order to consider uncertainties of imputation (Lüdtke et al., 2007).

\section{Results}

The results of the study will be presented now, regarding the questions whether learning transfer already takes place parallel to continuing vocational training through an improvement of performance in the workplace (research question 1) and which predictors cause transfer of learning at this time (research question 2). From the here identified predictors a structural equation model of collateral learning transfer is developed and empirically tested (research question 3 ) in the course of this chapter.

\subsection{Research question 1}

In order to answer research question 1: "Does learning transfer already occur parallel to the training? the following hypothesis was formulated:

H1: Parallel to the training the learned is already transferred to the workplace.

To accept or reject this hypothesis the following determination was made: Transfer of what is learned takes place parallel to the training when the means of the latent variables of the transfer success (performance at the workplace), and the transfer situation are at least 4.0. This threshold was chosen because as the data was gathered on a 7-point scale, from a linguistic point of view on this value the majority of the respondents show agreement and therefore successful transfer of the learned to the workplace.

Table 3 shows the mean values of the scales transfer situation $(M=4.450)$, professional performance $(\mathrm{M}=4.471)$, and social-communicative performance $(\mathrm{M}=4.272)$ which are all above the threshold of 4.0. The descriptive analyses of the results show that even while the training is still being given an application of course content to the workplace takes place. 
Table 3: Statistics of the latent variables of the transfer success

\begin{tabular}{|l|c|c|c|}
\hline Latent variable & M & SD & N \\
\hline Transfer situation & 4.450 & 1.338 & 269 \\
\hline Professional performance & 4.471 & 1.486 & 258 \\
\hline Social-communicative performance & 4.272 & 1.474 & 261 \\
\hline
\end{tabular}

Nevertheless, the standard deviation of the latent variables should be noted. It cannot be concluded that the learning is already being transferred by all participants equally in the workplace in parallel with the course. It can, however, be noted that there is predominant agreement regarding the transfer of the learned already at the middle of the course (after six of ten trainings days).

To conclude, parallel to attending the training both possibilities of application of the newly learned in the workplace (transfer situation), and transfer of learning (professional performance, social-communicative performance) are possible. Thus, collateral learning transfer takes place and hypothesis $\mathrm{H} 1$ is accepted.

The predictors of collateral learning and their causal relations will be investigated next.

\subsection{Research question 2}

To consider research question 2: "What are the predictors of collateral learning transfer?" the effects of the collected latent variables on the learning transfer (gathered as professional performance and social-communicative performance) are analyzed. In order to identify predictors of the transfer success parallel to the training, the following hypotheses were tested:

H2.1: The trainee characteristics determine collateral learning transfer.

H2.2: The training and learning conditions determine collateral learning transfer.

H2.3: The transfer orientation of the training determines collateral learning transfer.

H2.4: The transfer motivation of the learner determines collateral learning transfer.

H2.5: The organizational transfer climate determines collateral learning transfer.

H2.6: The transfer situation determines collateral learning transfer.

For each of the hypotheses to be tested a structural equation model was estimated. The presentation of results is in the order of the hypotheses, beginning with the impact of trainee characteristics on collateral learning transfer.

H2.1: Trainee characteristics

The latent variables conscientiousness $(\mathrm{r}=.07, \mathrm{p}=.452)$, self-efficacy $(\mathrm{r}=.02$, $\mathrm{p}=.839)$ and work identification $(\mathrm{r}=.18, \mathrm{p}=.013)$ have standardized regression weights (also called path coefficients) which are meaningless according to Chin (1998) as they are lower than $r<.20$. The trainee characteristics have no significant effect $($ all $\mathrm{p}<.01)$ on collateral learning (model fit: $\chi^{2} / \mathrm{df}=1.364$, RMSEA $=.035$, $\mathrm{CFI}=.951, \mathrm{SRMR}=.048$ ). Consequently, the trainee characteristics cannot be considered as predictors of learning transfer that occurs alongside training. 
H2.2: Training and learning conditions

Like the trainee characteristics, neither the training methods $(\mathrm{r}=.04, \mathrm{p}=.721)$, nor the situatedness of the learning environment $(\mathrm{r}=.18, \mathrm{p}=.186)$, nor the competence support $(\mathrm{r}=.11, \mathrm{p}=.321)$ have a significant effect on collateral learning transfer (model fit: $\chi^{2} / \mathrm{df}=1.328, \mathrm{RMSEA}=.033, \mathrm{CFI}=.956, \mathrm{SRMR}=.048$ ).

\section{H2.3: Transfer orientation of the training}

In contrast to the trainee characteristics, and the training and learning conditions has the transfer orientation of the training a significant effect on collateral learning transfer $(\mathrm{p}<.001)$. The regression has a medium weight $(\mathrm{r}=.41)$. In addition, the transfer orientation of the training explains $17 \%$ of the variance of the learning transfers during the training (model fit: $\chi 2 / \mathrm{df}=1.677$, RMSEA $=.048, \mathrm{CFI}=.944$, $\mathrm{SRMR}=.045$ ).

\section{H2.4: Transfer motivation}

The transfer motivation has a significant causal effect of medium size on collateral learning transfer $(\mathrm{r}=.47, \mathrm{p}<0.001)$. The transfer motivation also explains $22 \%$ of the variance of learning transfer that occurs parallel to the training (model fit: $\chi_{2} / \mathrm{df}=1.570, \mathrm{RMSEA}=.044, \mathrm{CFI}=.952, \mathrm{SRMR}=.043$ ).

\section{H2.5: Organizational transfer climate}

From the standardized model results it can be concluded that the attitude-related transfer support from the superior is the only one of the three latent variables of the organizational transfer climate that has no significant effect on collateral learning transfer $(\mathrm{r}=.013, \mathrm{p}=.887)$. Whereas both the action-oriented transfer support from the superior $(\mathrm{r}=.282, \mathrm{p}<.001)$, and the transfer climate in the team $(\mathrm{r}=.356, \mathrm{p}<.001)$ are significant predictors of collateral learning transfer. The organizational transfer climate explains $34 \%$ of the variance of collateral learning transfer (model fit: $\chi_{2} / \mathrm{df}=1.229$, RMSEA $=.028, \mathrm{CFI}=.972, \mathrm{SRMR}=.045$ ).

\section{H2.6: Transfer situation}

The transfer situation has a strong effect on collateral learning transfer $(\mathrm{r}=.52$, $\mathrm{p}<0.001$ ) and explains $27 \%$ of the variance (model fit: $\chi 2 / \mathrm{df}=1.980$, RMSEA $=057$, $\mathrm{CFI}=.917$, SRMR $=.063$ ).

Summary:

Through SEM the hypotheses $\mathrm{H} 2.1$ and $\mathrm{H} 2.2$ are rejected, whereas the hypotheses $\mathrm{H} 2.3, \mathrm{H} 2.4, \mathrm{H} 2.5$, and $\mathrm{H} 2.6$ are accepted. The following latent variables were identified as predictors of collateral learning transfer:

- Transfer orientation of the training

- Transfer motivation of the learner

- Transfer climate in the team

- Action-oriented transfer support from the superior

- Transfer situation

In a next step the causal relations between these predictors and collateral learning transfer are estimated using SEM. 


\subsection{Research question 3}

In order to answer research question 3: "In which causal relations do the predictors have an effect on collateral learning transfer?" the five previously as predictors of collateral learning transfer identified latent variables have been brought together in the same theoretical model. The latent variables transfer climate in the team, action-oriented transfer support from the superior, and transfer situation commonly represent the context "performance field" as an intermediate variable. Additionally, the latent variable attitude-related transfer support from the superior has also been integrated into the model, since the presumption was obvious that this affects the action-oriented transfer support from the superior.

Regarding the transfer of learning, which is already taking place in the workplace as an improvement of professional and social-communicative performance in parallel with the course attendance, the following system of hypotheses was constructed and tested:

H3.1: There is a reciprocal relationship between the transfer motivation of the learner and the transfer orientation of the training.

H3.2: The transfer motivation of the learner, and transfer orientation of the training have an effect on the context performance field.

H3.3: The attitude-related transfer support from the superior has an effect on the action-oriented transfer support from the superior.

H3.4: The context performance field determines the learning transfer.

The estimated model (see figure 1) has good fit indices $(\chi 2 / \mathrm{df}=1.139$, RMSEA $=.022, \mathrm{CFI}=.976$, SRMR=.080). As anticipated, the attitude-related transfer support from the superior has an effect on the action-oriented transfer support from the superior $(\mathrm{r}=.43, \mathrm{p}<.001$; see H3.3). Both the transfer motivation of the learner $(\mathrm{r}=.44, \mathrm{p}<.001)$ and transfer orientation of the training $(\mathrm{r}=.42$, $\mathrm{p}<.001$ ) have a medium effect on the context performance field (see H3.2). Moreover, there is a reciprocal relationship between these two $(\mathrm{r}=.39, \mathrm{p}<.001$; see H3.1), again with a medium effect size. The context performance field (represented by the transfer climate in the team, the action-oriented transfer support from the superior, and the transfer situation), however, has an effect of $r=.79(p<.001)$ on collateral learning transfer (see H3.4), which means a large causal effect.

The five predictors together explain $62 \%$ of the variance of collateral learning transfer through the intermediate variable "performance field" (see figure 1). The four hypotheses mentioned above are thus accepted. 

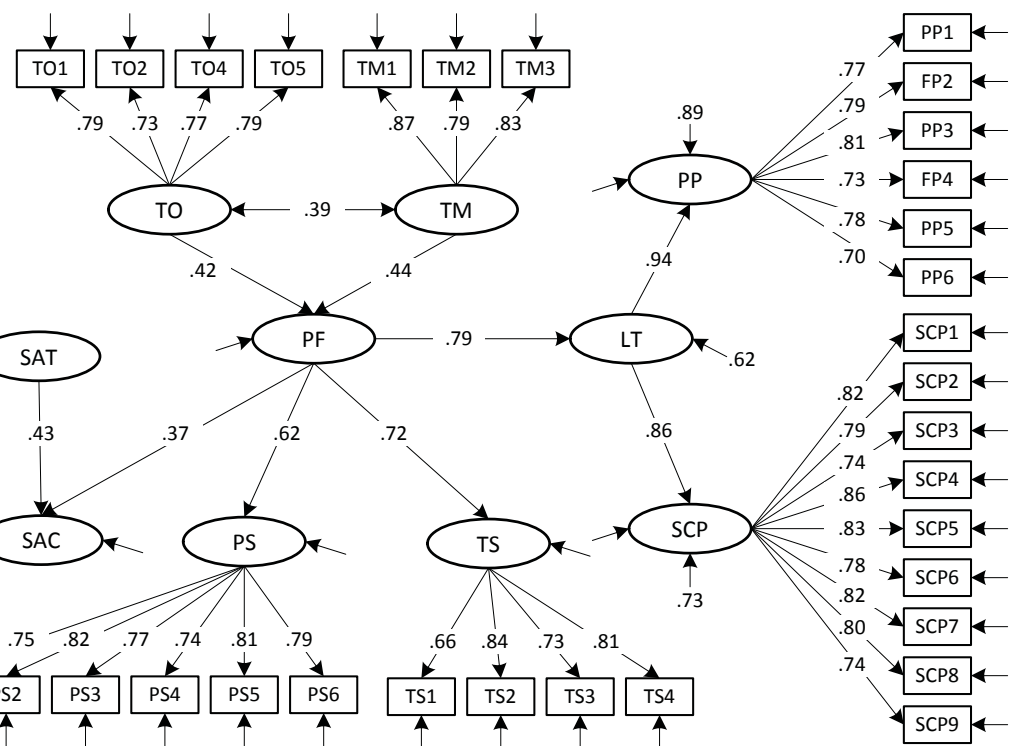

Comments:

TM: Transfer Motivation, TO: Transfer Orientation of the Training, PF: Context Performance Field, TS: Transfer Situation, PS: Peer Support, SAT: Superior Support (Attitude), SAC: Superior Support (Action), LT: Learning Transfer,

PP: Professional Performance, SCP: Sozial-Communicative Performance

\section{Figure 1: Predictors of Collateral Learning Transfer (SEM)}

As the research questions have been answered, the results will be discussed in the following.

\section{Discussion}

Based on the scale statistics, the respondents showed slight consent to transferring course contents to the workplace in parallel with the training participation. An increase in work performance was observed whilst still attending continuing vocational training.

According to the Four-Level-Evaluation-Model by Kirkpatrick (1967), the evaluation of level 3 (behavior or transfer) should not be carried out until two to three months after the training, as not all participants have the opportunity immediately after the end of a training to apply the learned at work (Kirkpatrick and Kirkpatrick, 2006). This approach cannot be supported with regard to the results of the present study. Even if this is not to generalize to all participants, the result suggests that an evaluation of transfer success already makes sense during the training course. Thus, barriers of learning transfer in the workplace could be identified in time and corresponding countermeasures in the learning field and/or in the performance field could be introduced.

The fact that an improvement in the performance at the workplace has been reported by the participants through the application of training content already parallel to the training might be explained by the didactic design of the training (project management certification) which is focused on the application of course content in the workplace. However, if knowledge is not directly applicable and learning transfer occurs as a consequence only after a delay, the suggestion by Kirkpatrick and Kirkpatrick (2006) to determine the transfer success (at least) a few months after the training should be followed.

While the trainee characteristics (conscientiousness, self-efficacy and work 
identification), the training and learning conditions (methods, situatedness of the learning environment and competence support) as well as the attitude-related transfer support from the superior do not have a significant direct influence on the transfer of learning after 6 of 10 days of the training program, the following latent variables could be identified as predictors of collateral learning transfer: the transfer orientation of the training, the transfer motivation of the learner, the transfer situation at the workplace, the transfer climate in the team and the actionoriented transfer support from the superior. It should be noted here that the attitude of the superior has an indirect influence on the transfer of learning, as this acts on the action-oriented transfer support from the superior.

A structural model of collateral learning was developed in this study and could be confirmed through SEM (see figure 1). The model is based on the theoretical understanding that learning transfer should not be considered only as a phenomenon that occurs after the successful participation in a continuing vocational training program. It could be confirmed that within the framework of CVT the application of the previously learned happens in the workplace already alongside the training and thus learning transfer takes place before the end of the training program. Therefore, the two contexts learning field and performance field should not be considered separately. The structural model of this study combines the influences of both and at the same time shows the central importance of the performance field in terms of successful collateral learning transfer.

At the timely middle of the certification program the transfer orientation of the training (as the most important predictor of the learning field) has a medium effect on the performance field $(\mathrm{r}=.42, \mathrm{p}<.001)$, and stands in a reciprocal relation to the transfer motivation of the learner $(\mathrm{r}=.39, \mathrm{p}<.001)$, which also has a medium effect on the performance field $(\mathrm{r}=.44, \mathrm{p}<.001)$. The intermediate variable performance field, represented by transfer situation, transfer climate in the team and action-oriented transfer support from the superior, has a strong influence on the transfer of learning $(\mathrm{r}=.79, \mathrm{p}<.001)$. The model explains $62 \%$ of the variance of collateral learning transfer $(\chi 2 / \mathrm{df}=1.139 ; \mathrm{CFI}=.976$; RMSEA $=.022$; SRMR $=.080$ ). The structural model of learning transfer in parallel with the training is shown in simplified form in the following figure:

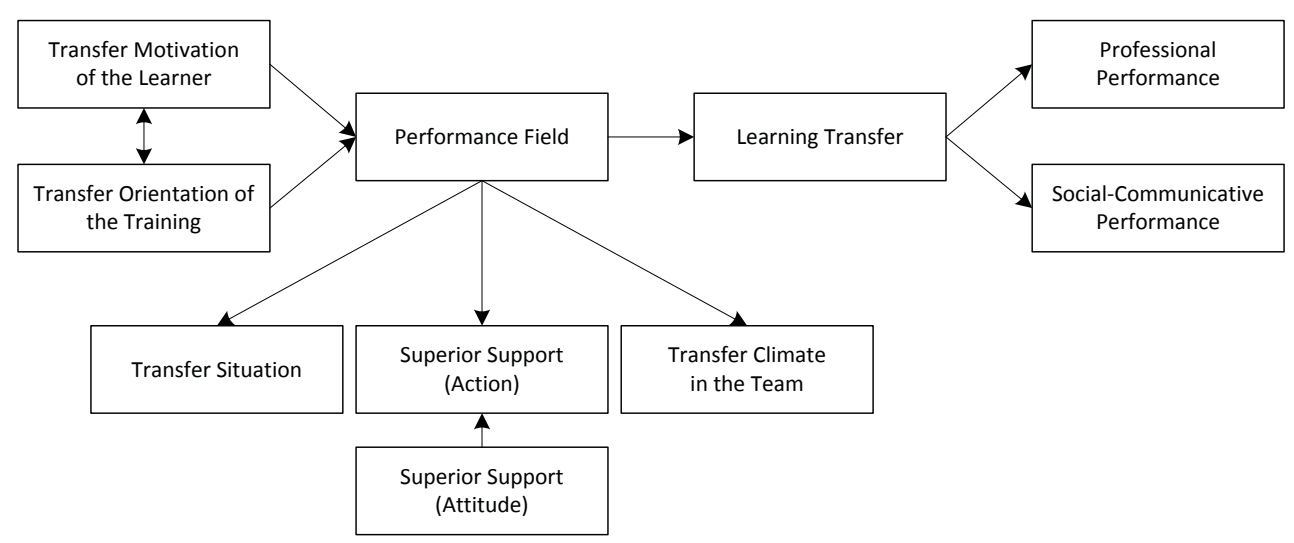

Figure 2: Structural Model of Collateral Learning Transfer

Although the empirical results derive from data collected during the training - and not, as the usual way at the end of the training or after several months - they can be discussed with regard to findings from other studies. Also Ford and Weissbein 
(1997) and Rank and Wakenhut (1998) identified the work environment as a key determinant of learning transfer. As in the investigation presented here, they were referring to the transfer climate, job support and possible applications. The organizational transfer climate as an important influencing factor was also found out by Baumgartel and colleagues (1984). The role of the superior in terms of a successful learning transfer has also been emphasized already by Huczynksi and Lewis (1980), and Kirkpatrick (2006). The transfer motivation of the learner, which was referred to as the strongest predictor in the Learning Transfer System Inventory (LTSI, Holton et al., 2000) by Wirth and colleagues (2009), acts in the structural model of this research, together with the transfer orientation of the training on the performance field. A design of training, which coincides with the work context, was discussed already by Thorndike and Woodworth (1901) and is also within the scope of the above presented structure model an important factor influencing the collateral learning transfer.

However, the research results of Wirth and colleagues (2009) that the positive attitude of the manager and the general self-efficacy (as direct effects) are conducive to transfer could not be confirmed. Also the trainee characteristics and the general training and learning conditions (Baldwin and Ford, 1988) have no direct influence on the transfer of learning in the presented study.

Despite the fact that in the present research more factors have been studied regarding their influence on learning transfer than in the study by Gessler (2012) his model could be confirmed in its basic structures - even though the time points of measurement are different (3-9 months after the training in Gessler's study and in the case of the presented study parallel to the training). In both studies, the transfer motivation of the learner, the transfer orientation of the training, the transfer support from superiors and colleagues, and the transfer situation in the workplace could be identified as significant predictors of learning transfer. Consequently, both the learning field and the performance field are key determinants for successful learning transfer. The structural model of collateral learning transfer goes beyond as it differentiates the transfer support provided by the supervisor in the two dimensions of attitude and action.

Overall, the empirical results highlight the central importance of the work environment for learning transfer. But also the transfer orientation of the training and the transfer motivation of the learner are highly influential regarding the improvement of work performance parallel to the training.

\subsection{Limitations and suggestions for future inquiry}

As a limitation of the present investigation, the type of data collection could be mentioned and discussed. The results are solely based on self-assessments of the participants. According to Schuler (1989) self-assessments can be described as profitable if the respondents do not have to worry that their statements bring along negative consequences (including promotion prospects and salary development). Sonntag and Schäfer-Rauser (1993) rather see a big potential in the self-assessment of professional skills and refer to this as a promising access to expanding the information base for company training and support measures. The sample consists of adults who are experts in their field of work and therefore should be able to realistically assess their personal learning transfer (Gessler, 2012).

Due to the research design no objective measurement of the transfer success was carried out. Moreover, the ultimate contribution of the learning transfer to the success of the company (return on investment) is missing. 
The present study aims at answering the question whether transfer of learning already takes place during continuing vocational training. The interpretation of the results is therefore limited to the time point of data collection (training half). As a consequence, no statements can be made about the development of the predictors over time and the sustainability of the learning transfer beyond the end of training. In a next step, the question should be raised whether collateral learning transfer leads to sustained learning transfer.

In addition, the identified predictors explain in terms of the developed structural model only $62 \%$ of the variance in self-reported learning transfer in parallel with the training. Consequently, it remains unclear which factors are responsible for the proportion of not explained variance.

The results of the presented study should also be investigated in other fields of CVT in order to determine whether the structural model is replicable in another training context or whether it results from the chosen field of study (the context of project management).

Since the results are solely based on quantitative data, further problemcentered interviews with the same participants should be carried out in order to better interpret and understand the quantitative results and to draw further conclusions for the promotion of learning transfer in the training (learning field) and in the work environment (performance field) in parallel with the training participation.

The research presented is limited to the perspective of the participants. It would make sense also to take into account the perspective of superiors and trainers to obtain further conclusions on predictors and conditions of successful learning transfer.

After this discussion of the limitations of the study and suggestions for future inquiry the contribution of the presented research results regarding transfer of learning research and practice is shown.

\subsection{Contribution to transfer of learning research and practice}

Contrary to the widespread understanding of transfer of learning, which refers to the generalization and sustainable use in the workplace of what has been learned in a training (Baldwin and Ford, 1988), it is apparent from the results of the presented research that an increase in work performance by application of the course content already happens parallel to continuing vocational training.

In teaching skills Yelon and Ford (1999) differentiate between closed skills and open skills. Regarding closed skills, specific skills are to be learned, which are identical to the environment in which they are to be transferred. If, however, learning principles are taught, these are called open skills. Here, there is not a single correct way of application, but a freedom in performance as it is given in the presented study. Under such conditions, transferring learning to the workplace takes place not only until after the completion of a training program, but rather alongside training. In this respect, the term collateral learning transfer was introduced.

The critical phase for learning transfer is therefore not only directly after the training, such as stated by Baldwin and Ford (1988) and Noe (1986), but starts during the training. Hence, the learning field and the performance field should not be considered as two separate systems in the promotion of learning transfer. They are rather closely related (see also Gessler, 2012). Accordingly, the learning environment should be designed in a way which is conducive to learning transfer 
by directly linking the learning content and the own project or the individual work content of the learner (predictor: transfer orientation of the training) (Hense and Mandl, 2011).

Neither the trainee characteristics nor the training and learning conditions, but the conditions in the company in particular are of importance in terms of collateral learning transfer. This includes whether the workplace offers the possibility of applying the newly acquired knowledge and skills (transfer situation), and whether the team and the superior are open for changes and supporting the learning transfer. A positive attitude of the superior towards the application of the training content by its employee, however, is not sufficient to promote the transfer of learning. Rather, it requires a discussion of concrete possibilities of application or action.

From the results it can be concluded that the establishment of a support system in the company is desirable, which already allows for and promotes the transfer of training contents in the context of work in parallel with the training. In this respect, Lemke (1995) assumes that the transfer of learning from the learning field to the performance field can be managed. He also postulated that the transfer management plays an active role in enhancing the effectiveness of training, which is connected to the quality management, increases the innovation capacity and is able to realize cost savings. Müller and Soland (2009) see the transfer management as a holistic operational task in which many people are involved: the learners, the trainers, the human resource development, the superiors, the colleagues and the management of the entire company. They then consider transfer management to be effective when creative ways are found to inspire people to continue learning and to support these processes. In this respect, learning should be understood as a basic function of enterprises.

In addition, it can be deduced from the empirical results of the presented study that transfer management is already important alongside a training program. It should be realized not only before and after CVT, but also parallel to the training. It is therefore recommended to support learning transfer processes in a systematic, active and ongoing way so that a personal development measure has its intended effect in the end (see also Solga, 2011). CVT should therefore be accompanied by a transfer management which begins before the training starts, continues alongside the training and remains far beyond its end. A transfer-promoting design of training programs, which according to Diesner and Seufert (2010) represented the most important task of education management of companies, can still be regarded as highly significant with regard to successful learning transfer. Unfortunately, only few companies have a support system to assure learning transfer (Müller and Soland, 2009). Anyway, the transfer process within the company should be taken seriously by superiors and the department for human resource development, and further support for successful learning transfer should be demanded by the employee when required.

The strong effect of the transfer orientation of the training on collateral learning transfer shows how important it is to highlight possible applications of the training content into practice (the workplace of the learners) in the learning field (training). Moreover, the work experiences of the learners should be addressed and brought together with the training content. In doing so, first transfer experiences should be reported and reflected in the training. However, even the training with the best transfer orientation and support for learners has only a little contribution to successful learning transfer if the conditions in the company impede the application of the learned. 
This research could contribute to a better understanding regarding the influencing factors of learning transfer alongside CVT. Moreover, not only the impact of the training design, but the high importance of the work environment (performance field) in terms of a positive organizational transfer climate and possibilities of application turned out. Consequently, the evaluation of the effectiveness of training should not be carried out only at the end of the training program or even several months later. It should rather be an integral part of the training itself in order to foster the transfer of learning parallel to the training. Thus, at an early stage factors could be identified and corrected both in the learning field and in the performance field that hinder the transfer process, according to the motto: "the most important purpose of evaluation is not to prove, but to improve" (Stufflebeam, 2002, p.283).

\subsection{Summary}

The results of the presented study show that if newly acquired knowledge is directly applicable (as in the present investigation) the learned is transferred to the workplace in the progress of the training program. In parallel with the training the participants reported an improvement in their work performance. As a consequence it can be concluded that learning transfer from the learning field to the workplace already takes place alongside continuing vocational training.

Moreover, predictors of the learning transfer at this stage were identified and analyzed with regard to their causal relationships and effect on learning transfer using structural equation modeling. Transfer of learning that takes place accompanying a training was designated as part of this research as collateral learning transfer. The following predictors of collateral learning transfer were identified: the transfer orientation of the training, the transfer motivation of the learner, the transfer climate in the team, the action-oriented transfer support by the superior, and the transfer situation at the workplace. Together they explain $62 \%$ of the variance of collateral learning transfer (gathered as professional and socialcommunicative performance).

Because transfer of learning already takes place during CVT, it can be derived from the research results that the transfer success should be evaluated in the course of training in order to carry out early corrective measures regarding the promotion of learning transfer if necessary - both in the learning field and in the performance field. 


\section{References}

Alliger, G.M.; Tannenbaum, S.I.; Winston, B.; Traver, H. \& Shotland, A. (1997). A meta-analysis of the relations among trainee criteria. Personnel Psychology, 50(2), 341-358.

Baldwin, T.T. \& Ford, J.K. (1988). Transfer of Training: A Review and Directions for Future Research. Personnel Psychology, 41(1), 63-105.

Bates, R.A.; Kauffeld, S. \& Holton, E.F. (2007). Examining the factor structure and predictive ability of the German-version of the Learning Transfer Systems Inventory. Journal of European Industrial Training, 31(3), 195-211.

Baumgartel, H.; Reynolds, M. \& Pathan, R. (1984). How personality and organizational-climate variables moderate the effectiveness of management development programmes: A review and some recent research findings. Management and Labour Studies, 9, 1-16.

Blume, B. D.; Ford, J. K.; Baldwin, T. T. \& Huang, J. L. (2010). Transfer of Training: A Meta-Analytic Review. Journal of Management, 36(4), 10651105.

Cheng, E.W.L \& Ho, D.C.K (2001). A review of transfer of training studies in the past decade. Personnel Review, 30 (1), 102-118.

Descy, P. \& Tessaring, M. (2006). Der Wert des Lernens: Evaluation und Wirkung von Bildung und Ausbildung. Dritter Bericht zum aktuellen Stand der Berufsbildungsforschung in Europa - Synthesebericht. CEDEFOP Reference Series 66. Luxemburg: Amt für amtliche Veröffentlichungen der Europäischen Gemeinschaften.

Dewey, J. (1938). Experience and Education. New York: MacMillan.

Diesner, I. \& Seufert, S. (2010). Trendstudie 2010: Herausforderungen für das Bildungsmanagement in Unternehmen. St. Gallen: SCIL Swiss Centre for Innovations in Learning.

Faulstich, P. (2009). Lernorte - Flucht aus der Anstalt. In P. Faulstich \& M. Bayer (Eds.), Lernorte. Vielfalt von Weiterbildungs- und Lernmöglichkeiten (pp. 7 27). Hamburg: VSA Verlag.

Ford, J.K., \& Weissbein, D.A. (1997). Transfer of training: An updated review and analysis. Performance Improvement Quarterly, 10, 22-41.

Gessler, M. (2010). Kompetenzbasiertes Projektmanagement (PM3): Handbuch für die Projektarbeit, Qualifizierung und Zertifizierung auf Basis der IPMA Competence Baseline Version 3.0. Nürnberg: GPM Deutsche Gesellschaft für Projektmanagement.

Gessler, M. (2012). Lerntransfer in der beruflichen Weiterbildung - empirische Prüfung eines integrierten Rahmenmodells mittels Strukturgleichungsmodellierung. Zeitschrift für Berufs- und Wirtschaftspädagogik, 108(3), 362-393.

Gessler, M. \& Sebe-Opfermann, A. (2011). Der Mythos „Wirkungskette“ in der Weiterbildung - empirische Prüfung der Wirkungsannahmen im „Four Levels Evaluation Model" von Donald Kirkpatrick. Zeitschrift für Berufs- und Wirtschaftspädagogik, 107, 270-279.

Hense, J. \& Mandl, H. (2011). Transfer in der beruflichen Weiterbildung. In: Zlatkin-Troitschanskaia, O. (Eds.), Stationen Empirischer Bildungsforschung (pp. 249-263). Wiesbaden: VS Verlag.

Holton, E.F.; Bates, R.A. \& Ruona, W.E.A (2000). Develpment of a Generalized Learning Transfer System Inventory. Human Resource Development Quarterly, 11(4), 333-360. 
Huczynski, A.A. \& Lewis, J.W. (1980). An empirical study into the learning transfer process in management training. Journal of Management Studies, 17, 227-240.

Inkpen, A.C. (1998). Learning and knowledge acquisition through international strategic alliances. Academy of Management Executive, 12(4), 69-80.

Kirkpatrick, D.L. (1967). Evaluation of Training. In L.C. Robert \& R.B. Lester (Eds.), Training and development handbook (pp. 87-112). New York: McGraw-Hill.

Kirkpatrick, J.D. (2006). Using Balanced Scorecards to Transfer Learning to Behavior. In D.L. Kirkpatrick \& J.D. Kirkpatrick (Eds.), Evaluating Training Programs. The Four Levels (pp. 82-94). San Francisco, CA: Berrett-Koehler.

Kirkpatrick, J.D. \& Kirkpatrick, D.L. (2006). Evaluating Training Programs. The Four Levels. San Francisco: Berrett-Koehler.

Lee, R.P.; Johnson, J.L. \& Grewal, R. (2008). Understanding the antecedents of collateral learning in new product alliances. International Journal of Research in Marketing, 25, 192-200.

Lemke, S. (1995). Transfermanagement. Göttingen: Verlag für Angewandte Psychologie.

Lüdtke, O.; Robitzsch, A.; Trautwein, U. \& Köller, O. (2007). Umgang mit fehlenden Werten in der psychologischen Forschung. Psychologische Rundschau, 58(2), 103-117.

Mandl, H.; Prenzel, M. \& Gräsel, C. (1992). Das Problem des Lerntransfers in der betrieblichen Weiterbildung. Unterrichtswissenschaft: Zeitschrift für Lernforschung, 20(2), 126-143.

Miner, A.S.; Bassoff, P., \& Moorman, C. (2001). Organizational improvisation and learning: A field study. Administrative Science Quarterly, 46, 304-337.

Moorman, C. \& Miner, A.S. (1998). Organizational improvisation and organizational memory. Academy of Management Review, 23, 698-723.

Müller, U. \& Soland M. (2009). Transfermanagement und Evaluation. In M. Gessler (Eds.), Handlungsfelder des Bildungsmanagements. Ein Handbuch (pp. 249-277). Münster: Waxmann.

Noe, R.A. (1986). Trainees' Attributes and Attitudes: Neglected Influences on Training Effectiveness. The Academy of Management Review, 11(4), 736-749.

Phillips, J.J. \& Schirmer, F.C. (2008). Return on Investment in der Personalentwicklung. Der 5-Stufen-Evaluationsprozess. Berlin, Heidelberg: Springer.

Rank, B. \& Wakenhut, R. (1998). Ein Bedingungsmodell des Praxistransfers. In B. Rank \& R. Wakenhut (Eds.), Sicherung des Praxistransfers im Führungskräftetraining (pp. 11-29). München; Mering: Hampp.

Reinecke, J. (2005). Strukturgleichungsmodelle in den Sozialwissenschaften. München: Oldenbourg.

Rubin, D.B. (1987). Multiple imputation for nonresponse in surveys. New York: Wiley.

Rump, J., Schabel, F., Alich, D. \& Groh, S. (2010). Betriebliche Projektwirtschaft. Mannheim: Hays.

Ruona, W.E.A; Leimbach, M.; Holton, E.F. \& Bates, R. (2002). The relationship between leaner utility reactions and predicted learning transfer among trainees. International Journal of Training and Development, 6(4), 218-228.

Schuler, H. (1989). Fragmente psychologischer Forschung zur Personalentwicklung. Zeitschrift für Arbeits- und Organsiationspsychologie, 33, 3-11. 
Solga, M. (2011). Förderung von Lerntransfer. In J. Ryschka, S. Solga \& A. Mattenklott (Eds.), Praxishandbuch Personalentwicklung. Instrumente, Konzepte, Beispiele (pp. 339-368). Wiesbaden: Gabler.

Sonntag, K. \& Schäfer-Rauser, U. (1993). Selbsteinschätzung beruflicher Kompetenzen bei der Evaluation von Bildungsmaßnahmen. Zeitschrift für Arbeitsund Organisationspsychologie, 37, 163-171.

Stufflebeam, D.L. (2002). The CIPP Model for Evaluation. In D.L. Stufflebeam, G.F. Madaus \& T. Kellaghan (Eds.), Evaluation in Education and Human Services // Evaluation models. Viewpoints on educational and human services evaluation (pp. 279-317). Dordrecht: Kluwer Academic Publishers (49).

Thorndike, E.L \& Woodworth, R.S. (1901). The influence of improvement in one mental function upon the efficiency of other functions. Psychological Review, $8,247-261$.

Urban, D. \& Mayerl, J. (2014). Strukturgleichungsmodellierung. Ein Ratgeber für die Praxis. Wiesbaden: Springer VS.

Wirth, R.; Kauffeld, S.; Bates, R. \& Holton, E.F. (2009). Katalysatoren und Barrieren für den Transfererfolg: Das Lerntransfer-System-Inventar. In S. Kauffeld, S. Grote \& E. Frieling (Eds.), Handbuch Kompetenzentwicklung (pp. 79-104). Stuttgart: Schäffer-Poeschel.

Yamkovenko, B. (2009). Dispositional Influences on the Intent to Transfer Learning: A Test of a Structural Equation Model. Louisiana State University.

Yelon, S.L., \& Ford, J.K. (1999). Pursuing a multidimensional view of transfer. Performance Improvement Quarterly, 12, 58-78. 
